This item was submitted to Loughborough's Research Repository by the author.

Items in Figshare are protected by copyright, with all rights reserved, unless otherwise indicated.

\title{
Frederick Law Olmsted and the cultural geography of southern slave autonomy
}

PLEASE CITE THE PUBLISHED VERSION

http://dx.doi.org/10.1080/0144039X.2017.1284906

PUBLISHER

(c) Taylor \& Francis

VERSION

AM (Accepted Manuscript)

\section{PUBLISHER STATEMENT}

This work is made available according to the conditions of the Creative Commons Attribution-NonCommercialNoDerivatives 4.0 International (CC BY-NC-ND 4.0) licence. Full details of this licence are available at: https://creativecommons.org/licenses/by-nc-nd/4.0/

\section{LICENCE}

CC BY-NC-ND 4.0

\section{REPOSITORY RECORD}

Armstrong, Catherine M.. 2019. "Frederick Law Olmsted and the Cultural Geography of Southern Slave Autonomy”. figshare. https://hdl.handle.net/2134/23420. 
Frederick Law Olmsted and the Cultural Geography of Southern Slave Autonomy

Abstract: Frederick Law Olmsted's account of his journeys through the southern states, undertaken from 1852-57 reveals that Olmsted, in whom a sense of place was especially strong, characterised enslaved people's relative freedom by place, delineating the plantation (even its slave quarters) as the areas of strictest control while liminal spaces at the edge of plantations, as well as roads, rivers, towns, markets and cities represented places of autonomy. These sites became places of resistance, with Olmsted contrasting his depictions of supposedly docile, naïve, slow-witted slaves on the plantation, with those more articulate, confident and able whom he met on the margins. In revealing the potential of African-Americans to live as free people in the United States, Olmsted reinforced the normalisation of the plantation for slave experience. This chapter will explore examples such as the landscape strategies of southern maroons and Olmsted's slaves’ autonomy by road, river and sea.

Keywords: geography, landscape, autonomy, resistance, antebellum south.

Frederick Law Olmsted's journey to the notorious Great Dismal Swamp in North Carolina led him to encounter the second generation maroon swamp inhabitants, who survived by stealing, gaining charity from slaves and occasionally hiring themselves out to poor labourers. He also met the enslaved lumbermen who often supported the maroons. Olmsted wrote 'the slave lumberman then lives measurably as a free man, hunts, fishes, eats, drinks, smokes and sleeps, plays and works, each when and as much as he pleases...no driving at his work is attempted or needed'. ${ }^{1}$ Other slaves in the swamps removed trees from fishing grounds, a process which involved divers taking gunpowder below the water line to blast the trees out. For such heroics they were rewarded with whiskey and high wages by their employers and these men were

\footnotetext{
${ }^{1}$ Frederick Law Olmsted, The Cotton Kingdom, ed. Arthur M. Schlesinger Sr. (New York: Da Capo Press, 1984), 114.
} 
considered very brave. ${ }^{2}$ These swamp workers achieved status and considerable financial gain and also were some of the few enslaved men who could express an independent masculine identity. This article explores how in Frederick Law Olmsted's 1861 book The Cotton Kingdom, slave autonomy intersected with the Southern landscape.

Albert Fein argues that Olmsted’s work reveals much about slavery’s impact on landscape. ${ }^{3}$ I agree, and further suggest that Olmsted also illuminates the reciprocal impact of the landscape on slaves' lives and experiences. Historians of slavery have been mixed in their responses to Olmsted's observations, from Ulrich B. Phillips' objections that he was condescending and niggling, through to John Blassingame's assertions that although his work was useful but flawed, as with equally flawed slave narratives, historians should still make use of his ideas. Robert Fogel and Stanley L. Engerman agree, suggesting that Olmsted was coloured by 'northern chauvinism'. But Olmsted’s outlook was not a typically sectional one; at one point he challenged a New York Times caricature of a slave owner as 'a jolly fox hunting idler' and he deliberately tried to avoid a partisan approach to what he saw. ${ }^{4}$

Olmsted's travel accounts were published first in the New York Times as a series of letters, then as three volumes before being finally gathered in 1861 into a single volume. This article is not concerned with the literary merit of his work, but rather his political and economic responses to slavery as a system, especially his discussions of race and the landscape. On his travels, Olmsted was most interested in flora, agriculture, soil, drainage, housing, open spaces and public health. His intention was to laud free labour and to challenge idea of African Americans' inherent slavish tendencies. According to one of his earliest biographers, Broadus Mitchell, before he left for his journeys, undertaken between 1852 and 1857, Olmsted thought that the misguided South, finding herself in this 'unfortunate circumstance' should gently be shown error of her ways. He did not blame the slave owners of the south for the backward condition of the region and instead, Mitchell wrote, 'Olmsted did what he could to save the pot from boiling over'. 5

\footnotetext{
2 Ibid, 119.

${ }^{3}$ Albert Fein, 'Introduction', in Dana White \& Victor Kramer, eds. Olmsted South: Old South Critic/New South Planner (Westport, CT.: Greenwood Press, 1979), xx.

${ }^{4}$ Olmsted, The Cotton Kingdom, 601.

${ }^{5}$ Broadus Mitchell, Frederick Law Olmsted: A Critic of the Old South (Baltimore: Russell \& Russell, 1924), xi.
} 
As an experienced agriculturalist, proponent of scientific agrarianism and from 1847 onwards owner of his own farm, first in Connecticut and later on Staten Island, Olmsted thought that he was uniquely placed to comment on the economic life of the south and the relationship between the enslaved workers that he saw there and their understanding of the landscape. He criticised southerners' deliberate practice of exhausting the land because, to a certain extent, it rendered even the grand plantation houses as temporary structures. 6

Although he spent much time discussing slavery with William Lloyd Garrison, Olmsted was most definitely against immediate abolition, and instead was keen to see changes that would ameliorate the southern slaves' conditions. He wanted slaves to be paid for their labour and their produce, but judged that if slavery were to end, most African Americans would opt to return to Africa. Therefore on his travels around the south, Olmsted looked for examples within slavery that specifically pointed against the norm and spoke of the potential for change and renewal in the south and her people, both black and white. He spent time trying to get a sense of the cultural environment in a particular locale, but then recorded unique experiences that allowed him to reflect novelty. Karla Spurlock Evans argues that Olmsted tried to give slaves agency and, when on occasion he was a harsh critic of their behaviour, this was because of his desire to show the deleterious impact of the system. ${ }^{7}$ However, Evans argues that Olmsted's view of slavery was not monolithic and his subtle acknowledgement that some slaves were able to achieve a virtual freedom makes Olmsted's ideas chime with recent slavery studies. At times, too, Olmsted allowed slaves their own voice within his narrative - when engaging them in conversation, for example - and gave them a sense of humanity. ${ }^{8}$

In response to the spatial turn, historians have begun to grapple with the connection between the geography of the plantation, the region, the state and the south as a whole, and the relative autonomy achieved by many enslaved people. The issues of flexibility with one's own time and the potential to earn one’s own money illustrate how slaves could facilitate a more autonomous lifestyle, but the issue of 'place' has hitherto

\footnotetext{
${ }^{6}$ Olmsted, The Cotton Kingdom, xxiii.

${ }^{7}$ Karla Spurlock Evans, 'Frederick Law Olmsted’s Journeys in the Slave South', in White \& Kramer, eds. Olmsted South, 53.

${ }^{8}$ For example, Olmsted, The Cotton Kingdom, 62.
} 
been neglected. ${ }^{9}$ Direct descriptions of how the enslaved perceived the natural or designed landscapes around them are few, but historians can interpret hints and silences in other sources.

This article is concerned with the ways that the enslaved depicted in Olmsted's book engaged with different landscapes, especially those on the margins, for example woods, uncultivated areas and roads, and it explores how black perceptions of the landscape were distinctive to those of whites. It argues that African Americans understood these marginal spaces both literally and metaphorically as 'places of escape', depending on whether movement within them was considered sanctioned, tolerated or illicit by masters. These places operated as borderlands for the enslaved, where they were able to exercise a certain degree of autonomy but were also under constant threat from attempts at control by the planter regime. It will also argue that on the plantation, where on the surface white domination was unchallenged, the enslaved used southern spatial hierarchies to carve out their own safer, but never truly safe, places.

Through an examination of a northern white man's perceptions of slaves' relationships with the landscape, we can access some of these complexities. White commentators recognised the importance of manipulating representations of space as it was a crucial element of control over the enslaved. White contemporaries shared slaves' association of place with autonomy. As the 1820 Missouri Compromise carved up the natural environment in relation to slavery, increasingly, for all Americans, freedom became 'a place'. Frederick Law Olmsted's account of his journeys through the southern states reveals that he, in whom a sense of place was especially strong, characterised relative freedom by place, delineating the plantation (even its slave quarters) as the area of strictest control while liminal spaces at the edge of plantations, as well as roads, rivers and also towns, markets and cities represented places of relative autonomy for enslaved people. ${ }^{10}$ Potential for travel, to see relatives, to go to market or to encounter new ideas were contrasted by them with the controlled environment of the plantation. These sites became places of resistance, with Olmsted contrasting supposedly docile, naïve, slowwitted slaves on the plantations, with those more articulate, confident and able whom he

\footnotetext{
${ }^{9}$ Philip D. Morgan, Slave Counterpoint: Black Culture in the Eighteenth Century Low Country and Chesapeake (Williamsburg, VA.: Omohundro Institute, 1998).

${ }^{10}$ For example, Olmsted, The Cotton Kingdom, 121, 187.
} 
met in marginal places. As Lawrence Powell argues in his introduction to Olmsted's The Cotton Kingdom, Olmsted's ideological strain must not be ignored; his northern middle class upbringing allowed him to judge harshly the South's poor whites living on the margins and his views on the economics of slavery cannot be taken at face value either. ${ }^{11}$ But his observations of the enslaved working and moving through many types of landscape, and his conversations with them, provide a fruitful resource complementing the works that were published around the same time calling for immediate abolition. And Olmsted's especial focus on the landscape and its social meaning throughout his life makes him an interesting commentator on this matter.

The scholarship on the influence and experience of slaves in the landscape has often focused on the shared experience of slaves and whites with both influencing its creation and development. Charles Joyner argues that while many of the physical aspects of the built environment might be Euro-American, the 'grammar' or underlying structure of understanding of the slaves was African. ${ }^{12}$ Although within his published narratives, Olmsted never wavered from the idea of the master's total metaphorical control of the plantation landscape, in his private correspondence something else is evident. Even within the plantation, assumed by Olmsted to be the site of the height of the master's control, he encountered places in which the enslaved population were able to craft some sense of independence. In a letter to Charles Brace written from New Orleans in February 1853, he wrote that the slave cabin was a place of partial African American autonomy. However, this autonomy could be subverted in gendered cases when the master invaded his female slaves' space. Olmsted delicately wrote to his friend: 'you can’t go into their cabins at night, not so much because their master might shoot you. He himself won't go into them, from delicacy unless with special purpose and such purpose as he wouldn't let another man meddle in'. ${ }^{13}$ In his published narrative, the theme of gender is less apparent as Olmsted rarely discussed female slaves, and his encounters with more autonomous slaves on the landscape peripheries were all with men.

\footnotetext{
${ }^{11}$ Ibid, XX.

${ }^{12}$ Quote from Charles Joyner in Leland Ferguson, Uncommon Ground: Archaeology and Early African America 1650-1800 (Washington DC.: Smithsonian Books, 1992), xlii.

13 'Letter to Charles Brace 23/2/1853 from New Orleans', The Papers of Frederick Law Olmsted, vol II. Slavery and the South, ed. Charles Capen McLaughlin (Baltimore: Johns Hopkins, 1981).
} 
The understanding of the landscape by blacks and whites of South Carolina especially, and to a lesser extent Virginia, North Carolina and Georgia developed symbiotically as both races underwent a process of creolization. ${ }^{14}$ They lived in close proximity and shared the same natural and built environment. The 'Big House' and the slave quarters were part of a single landscape. ${ }^{15}$ Both races held concepts of time which were defined by their relationship to the agricultural patterns of the colony. ${ }^{16}$ Black and most white homes were built of similar materials and the ritual and medicinal connection with the landscape was strong in the traditions of both races. Of course, whites controlled the use of space by the slaves; they often defined where and how they lived. ${ }^{17}$ Some planters preferred their slave accommodation to be out of sight, not spoiling the vistas on their plantation, whereas others saw their slaves as a status symbol so had their huts at the front of the property. Slaves' houses often had more in common with outbuildings than homes, and were seen as such on estate maps. ${ }^{18}$ But the cultural process was not only one-way. Whites shared black experience too, and sometimes landscape use reflected a certain autonomy and independence for the enslaved population. Slaves considered the plantation their home and they commandeered plantation spaces for their own entertainments. Black house servants controlled certain parts of the house, such as the kitchen or the nursery and also many of the outbuildings on the estate such as stables, icehouses and storehouses. Some planters allowed the enslaved to cultivate their own gardens and in many cases they could decorate their homes as they pleased. ${ }^{19}$ Their houses often had 'root cellars': spaces peculiar to slave quarters in which any food stolen from the white master might be kept cool and hidden. ${ }^{20}$

Much of the scholarly work in the last thirty years on slavery and landscape has been done by archaeologists working to find traces of evidence of slavery through material culture. In her survey of the findings of archaeologists on slavery, Theresa Singleton outlined the advent of African American archaeology in the 1970s, closely followed by the archaeology of the 'other' in which material culture was used to access

\footnotetext{
${ }^{14}$ Ibid, xli.

${ }^{15}$ John Vlach, Back of the Big House (Chapel Hill: University of North Carolina Press, 1993),xiv.

${ }^{16}$ Mechal Sobel, The World they Made Together (Princeton: Princeton University Press, 1987), 5.

${ }^{17}$ Ibid, 111.

${ }^{18}$ Vlach, Back of the Big House, 162.

${ }^{19}$ Ibid, 15, 167.

${ }^{20}$ Ferguson, Uncommon Ground, 58.
} 
the interior lives of subaltern people. ${ }^{21}$ This archaeology was rooted in black activism and also the desire to preserve historic sites associated with slavery and to provide the public with the tools with which to interpret them. The most recent generation of archaeologists has explored slaves' homes, foodways, status markers within African American society and power relations with white masters. Two themes have dominated their studies: the extent to which African origins were creolised to produce a hybrid identity and also the relative importance of white dominance and black resistance in the slave past.

Rebecca Ginsburg and, earlier, Dell Upton have examined the existence of unique black perceptions of the southern landscape and this must be understood in the light of white dominance and black resistance. ${ }^{22}$ Ginsburg suggests that there is a separate 'black cognitive landscape' and Stephanie Camp developed this concept. ${ }^{23}$ They both make use of standpoint theory: the idea that the enslaver and enslaved perceived of the single landscape very differently. The individual's multi-faceted perspectives are shaped and reinforced by their social and political experience. Ginsburg and Camp argue that the sense of place in the eighteenth and nineteenth century south was highly contingent on race. The black landscape changed over time and was indecipherable to whites. This was especially true of what I call 'landscapes of escape' used by temporary or permanent runaways. These landscapes provided brief moments of psychological escape from the trauma of slavery for the many slaves, often women, who had left for short periods, or provided shelter for those who had taken the decision to leave the plantation permanently. But it is also important to consider sanctioned movement through landscape. While, as Camp suggests, the movement of most slaves was limited by their masters who had control over issuing passes and punishing any unauthorised movement and truancy harshly, enslaved people were still able to develop what Camp refers to as a 'rival geography’. Some activities such as party going or attending religious services pushed the boundaries of sanctioned movement and operated in tolerated spaces while being tacitly acknowledged by both the master and the enslaved person as transgressions.

\footnotetext{
${ }^{21}$ Singleton, 'Archaeology of Slavery in North America’, 120.

22 Rebecca Ginsburg, 'Introduction’ and Dell Upton 'White and Black Landscapes in Eighteenth-Century Virginia’, in Ginsburg \& Ellis, eds. Cabin, Quarter, Plantation, 3, 135.

${ }^{23}$ Stephanie Camp, “I could not stay there”, Enslaved Women, Truancy and the Geography of Everyday Forms of Resistance’, Slavery and Abolition, vol 23, no. 3 (2002), 3.
} 
Understanding the role of marginal borderland places in slaves' lives helps us to reconstruct their mental world. Robert Fitts has shown that domestic slaves who live and work alongside their master in the same house were denied their own space and so could not perform their own cultural traditions with relation to the landscape. For these slaves, sanctioned trips out of the plantation house were a way to find unmonitored space, to meet and exchange information with other slaves. ${ }^{24}$ Camp argues that these plantation boundaries, while rigidly imposed by many white planters, were not perceived thus by the slaves, and their world was actually imagined as a continuous series of liminal spaces. But what can these marginal landscapes tell us about the issue of autonomy? Slaves' existence in these places with the permission of an owner or in defiance of him or her changes the meaning of these places. Camp directly linked the landscape to resistance. She argued that through truancy, slaves' use of the margins explicitly resisted 'the geography of containment' that epitomised slavery. This landscape use revealed not only individual and collective acts of resistance, for which the punishment was often very severe, but also served to further 'the long-term freedom struggle'. ${ }^{25}$ Singleton and B.L. Herman reinforce the idea that it is possible to map the spatial patterns of resistance of enslaved peoples as they moved through or lived in marginal hidden spaces. Herman coined the phrase 'locus of agency' to describe the function of these marginal spaces. ${ }^{26}$

Finseth confirms this idea by examining literature. He showed that slave narratives were also concerned with geographical spaces in which a slave might find freedom and that their over-arching narrative structure is about movement from place to place. ${ }^{27}$ Therefore a slave's search for freedom was always associated with a sense of place and movement through the landscape. He discusses the subcognitive ways of understanding nature as evidenced in myths, metaphors and folklore. He studied Harriet Beecher Stowe's lesser-known novel Dred: A Tale of the Great Dismal Swamp about the lives of slaves in that region of North Carolina. Stowe, he argues, makes the assertion that the wild landscape of the Dismal Swamp permits rebellion. Power is conferred by the

\footnotetext{
${ }^{24}$ Robert Fitts, 'The Landscapes of Northern Bondage', in Ginsburg \& Ellis eds. Cabin, Quarter, Plantation, 198.

${ }^{25}$ Camp, '”I could not stay there"', 7.

${ }^{26}$ Singleton, 'Archaeology of Slavery in North America', 134; .B.L. Hermann, 'Slave and Servant Housing in Charleston 1770-1820’, Historical Archaeology, 33 (1999), 88.

${ }^{27}$ Finseth, Shades of Green, 253.
} 
knowledge of particular secret hideouts and trails and so the wild landscape can also provide a sense of refuge from the dehumanising effects of life on the plantation. This power was often hard-won through series of repeated escape attempts and the gradual development of knowledge of the environment and its scale. But the realisation that an enslaved person could operate under the radar of white surveillance by moving through these wild landscapes was crucial.

Swamps were not always a successful place of refuge as shown in 1739 with the response to the Stono rebellion. The account of the uprising in the Daily Gazetteer of London said that whites killed 'about 30 and drove the rest into the swamps where they must either surrender or be put to the sword'. This use of the word 'swamp' as a place of refuge for the 'enemy' echoes earlier fears of the wild parts of the natural world harbouring Natives, and not the more contemporary thinking of white Carolinians that swamps made valuable agricultural land. ${ }^{28}$ These wild places were sites of both illicit and sanctioned slave movement. However, even in cases where slaves were in the swamp with permission of their owner, they were still able to gain autonomy from moving in that environment, as shown by Olmsted. The sense of security and independence achieved by the enslaved in moving outside the plantation remained constant from the colonial to the late antebellum eras. It can also be seen in 1831 when Nat Turner took refuge in the Great Dismal Swamp and evaded capture for a short while because his white trackers were reluctant to enter the wild landscape.

There are many occasions where Olmsted saw the landscape as a refuge or a sanctuary and Robert Detweiler's assessment of Olmsted's style saw much of the picturesque in his thinking. ${ }^{29}$ This also resonates with the heritage of the pastoral, the concept of the psychically regenerative power of nature. There are many echoes of the picturesque and the pastoral in Olmsted's depictions of slavery in the North Carolina swamp region recounted at the outset. Elsewhere in the book, he also described slaves hired out to labour on the railroads for a season who were able to command such high wages that their owners leased them out to the railroad companies, then hired in white

\footnotetext{
${ }^{28}$ Daily Gazetteer, Nov 17 1739, issue 1376.

${ }^{29}$ Robert Detweiler, ‘Transcending Journalism', in White \& Kramer, eds. Olmsted South, 75
} 
men to cover their plantation work paying wages by the day. ${ }^{30}$ Olmsted was keen to show that by becoming wage labourers, these enslaved men worked much more productively. This was not the only example noted of former slave plantations now using free labour. A plantation in Virginia owned by an anti-slavery proprietor was cultivated entirely by free Virginia-born labour of both races alongside Irish and German born immigrants because the slave labourers had been freed and had gone to Africa. According to Olmsted, they were still in touch with their former master. ${ }^{31}$ This ultimate expression of geographical mobility impressed Olmsted, and he suggested that the education and religious sincerity of the freedmen in Africa showed that they had considerably improved themselves moving there and thus the stain of slave status was removed. Olmsted was also impressed with the intelligence of a group of slaves he encountered in a turpentine forest outside Fayetteville, North Carolina. The slaves were working productively to harvest the turpentine and were he said 'unusually intelligent and cheerful', in contrast with the white people living in the forest who were 'poverty-stricken vagabonds'. This is an example of slaves and poor whites being in close proximity on the margins of a cultivated landscape and, in Olmsted's view, the African Americans were better placed to prosper in a modern economy. $^{32}$

Such marginal landscapes were also the site of independent slave work, work undertaken for the slaves' own profit. Philip Morgan discusses the eighteenth-century use of market gardening and livestock rearing by slaves to supplement their income, but Olmsted highlighted a less well-known extra income, describing the swamp areas around Natchez where slaves left the plantations to go into the swamps on a Sunday to harvest wood to make boards, which were then sold for a handsome profit. ${ }^{33}$ Such activity was also of mutual benefit to the slaves and the master on the edge of a plantation in Virginia; a group of mixed male and female slaves gathered wood and made charcoal by burning the wood in a large covered pit to sell to the plantation blacksmith. Olmsted observed this practice and then later discussed it with the master, who approved of it, seeing that it

\footnotetext{
${ }^{30}$ Olmsted, The Cotton Kingdom, 65.

${ }^{31}$ Ibid, 73.

32 Ibid, 146.

33 Ibid, 434; Philip Morgan, Slave Counterpoint: Black Culture in the Eighteenth-Century Chesapeake and Low Country (Chapel Hill, 1998).
} 
benefited both the blacksmith and the slaves who were able to earn a little money for themselves during the Christmas holidays. ${ }^{34}$

However, Olmsted was clear that such marginal wilderness sites also proved threatening to maroons, runaways or truants. They proved fruitful hunting grounds for slave trackers and their dogs, described in detail in an East Texas and Alabama context. ${ }^{35}$ Slave hunting, like other types of hunting, had both a pragmatic and a sporting function. A sportsman can be seen as a 'proxy warrior', representing the interests of his nation, his race, his class, his family, his community. At the time of Olmsted's visit, white identity in the South might be considered as an especially vulnerable category, infused as the region was with paranoia about the nation's intentions towards its slave society, but also about the behaviour of the enslaved people themselves. Throughout the colonial period, slave catching was a multi-cultural activity, both in the South and in the Caribbean, where, as well as whites, Native Americans and maroons were employed in this role. In the eighteenth century, John Brickell thought that slaves found the untamed landscape outside the plantations frightening because of the presence of the Native Americans; without the presence of these notorious slave trackers, Brickell believed far more slaves would run away. ${ }^{36}$ However, by Olmsted's time, the tracking role was the preserve of whites, so that it was a way of creating community and racial cohesion. An Alabamian who spoke to Olmsted accounted that 'some fellows take as much delight in it [slave hunting] as runnin' a fox'. ${ }^{37}$ The relationship between tracker and dog is also interesting because the choice, treatment and breeding of dogs for hunting has uncomfortable echoes in the language of breeding of slaves for work and naming practices of hunting dogs and enslaved men were often eerily similar, for example using classical motifs.

Throughout the Atlantic World many accounts of slave hunting depict the practice as essential for the maintenance of law and order. From 1696 in South Carolina, rewards were offered to those who recaptured runaway slaves and, from 1701, public relief was offered to anyone injured in the act of pursuing a runaway slave. ${ }^{38}$ At the same time slave

\footnotetext{
${ }^{34}$ Ibid, 68

${ }^{35}$ Ibid, 431-437.

${ }^{36}$ Brickell, Natural History, 263.

${ }^{37}$ Olmsted, The Cotton Kingdom, 437.

${ }^{38}$ L.H.Roper, 'The 1701 Act for Better Ordering of Slaves', William and Mary Quarterly, vol. 64, no. 2 (2007), 402.
} 
patrols were instigated: organized horseback groups designed to prevent the free movement of slaves, especially on Sundays when they were liable to leave their plantations. Slaves knew these men as patter-rollers or paddyrollers and sometimes considered them the lowest of the low of the whites in authority. Taxes and levies placed on slave owners financed slave patrols and constables (who supervised slave populations in cities). Olmsted discussed the economics of slave hunting, stating that an East Texan told him that 'nigger hunting is a business' and that he kept his best dogs to do this work. $^{39}$ Slave catchers on the other hand were private citizens who took advantage of rewards offered for the return of runaway slaves. Their work was generally supported by the local planter population, although slave catchers were urged to be cautious in their use of dogs because, as Sally Hadden notes, planters did not want their property to be 'bruised and torn by the dogs'. ${ }^{40}$ Walter Johnson described the 'carceral landscape' of paranoia that enveloped both slaves and slaveholders alike. ${ }^{41}$ Acknowledging the fear induced by slave patrols and catchers allows the historian to achieve a more nuanced understanding of slaves' perceptions of wild landscapes. While these places could offer freedom and independence to the enslaved, this was always limited by the allencompassing controlling nature of the system of slavery in the South.

As well as identifying single sites of negotiated autonomy, Olmsted examined the movement of slaves through the landscape. Here he referred not to truant or runaway slaves, but rather described sanctioned movement, which itself represented an escape from captivity, a sort of freedom. Sometimes these journeys permitted days, weeks and even months away from the plantation, such as in the case of the two slaves, an old man and a young boy, who Olmsted encountered on the road from Rockingham County, North Carolina to Columbia, South Carolina, gradually selling their 175 boxes of tobacco as they travelled. ${ }^{42}$ In Georgia, Olmsted encountered a group of enslaved people whose ownership of horses and carts enabled them to make their own way to church whenever

\footnotetext{
${ }^{39}$ Olmsted, The Cotton Kingdom, 387.

${ }^{40}$ Sally Hadden, Slave Patrols: Law and Violence in Virginia and the Carolinas (Cambridge, MA.: Harvard University Press, 2001), 80.

${ }^{41}$ W. Johnson, River of Dark Dreams: Slavery and Empire in the Cotton Kingdom (Cambridge, MA: Harvard University Press, 2013).

42 Olmsted, The Cotton Kingdom, 163.
} 
they pleased. ${ }^{43}$ This unusual amount of freedom in the landscape was almost certainly permitted by the owner or overseer, either of whom could have issued harsh punishments in reprisal. Finseth states that freedom was not the only value sought by slaves as they moved through the landscape and that community was of equal importance to them. ${ }^{44} \mathrm{An}$ individual's community lived not just on his or her plantation, but might also be spread around several neighbouring plantations. This was especially true of slaves who experienced being hired or leased out. They gained knowledge of new environments and develop new networks.

The enslaved were tied to particular pieces of land not only through their economic relation to it, but also because of kinship and friendship ties. When slaves moved through the landscape with or without the consent of their master, they tried to emulate the sense of community and security that the plantation may have given some but not all slaves. Olmsted's depiction of the situation in Georgia suggested that the slaves' control over this mode of transport had given them a measure of independence and had triggered the desire to attend religious worship and through knowledge of the local area, conceive of a community of slaves within it. Tolerated movement of the enslaved to and from market also formed part of economic activity on the margins of slave society, enabling them to trade and feed and cloth themselves without the onerous task falling on the master. In many cases they could also buy themselves luxuries such as tobacco and illicit alcohol that masters tried to prevent them from acquiring. Olmsted noted that in one case in the rice-growing country outside Savannah, a master and his family fed themselves on the surplus produced by his slaves. ${ }^{45}$

Olmsted felt that the majority of plantations were sites of white dominance and control. But his observations in Louisiana of plantations owned by free blacks also referred to them as sites of oppression and diminished economic opportunity. For him, it was the system of slavery that was at fault, no matter the colour of the master's skin. His observations of slave owning by free blacks in the southern Louisiana region were told through the voices of slaves that Olmsted encountered and engaged in dialogue. Twice he recounted meeting slaves on the road and discussing with them the neighbouring

\footnotetext{
${ }^{43}$ Ibid, 188.

${ }^{44}$ Finseth, Shades of Green, 253

${ }^{45}$ Olmsted, The Cotton Kingdom, 195.
} 
plantation owned by a black slave owner. 'Dey is very bad masters', said one, and another said that having black slave owners 'ain't right' and that 'free niggers' were the worst masters. ${ }^{46}$ The slaves in these cases felt able to express themselves when they left their plantations and met an outsider, who was not part of the regime of enslavement.

In conclusion, as Richard Schein has argued in his work interpreting 'ordinary landscapes', every space in the southern states was imbued with racial meaning. ${ }^{47}$ While the norms of slavery defined and restricted the slaves' experience of the landscape, there were also many ways in which they could subvert these norms. They created their own mental maps of the places through which they moved and often their subversions occurred in borderland places that were on the margins between cultivated land and socalled wilderness on the edge of plantation estates, or on the road. Sometimes these places were literal 'places of escape' where illicit movement by an enslaved person resulted in temporary or permanent freedom. However, slaves were never completely at liberty in these places because of the real or perceived threat from slave patrols or catchers. At other times the slaves were still under the nominal control of their master but achieved limited autonomy through sanctioned or tolerated movement or through work in wilderness areas. Olmsted's writing highlighting slave autonomy in the margins confirms the findings of some twenty-first century historians because he wanted to illustrate the economic, social and cultural potential of the African American population. His work is further evidence that scholars must now take geographic location as well as historical period and economic factors into account as determinants of achieving some measure of autonomy for enslaved people.

\footnotetext{
${ }^{46}$ Olmsted, The Cotton Kingdom, 321.

${ }^{47}$ Schein, 'Methodological Framework for Interpreting Ordinary Landscapes', 188.
} 